\title{
MODERN METHODS OF DETERMINING SHELF LIFE OF NUTRITION PRODUCTS AND WAYS OF ITS DEVELOPMENT
}

\author{
N. Frolova \\ National University of Food Technologies
}

\begin{tabular}{l} 
Key words: \\
Shelf life \\
Product spoilage \\
processes \\
Critical quality attributes \\
Programming \\
Testing \\
Kinetic models \\
\hline
\end{tabular}

Article history:

Received 05.09.2018

Received in revised form

28.09.2018

Accepted 18.10.2018

Corresponding author:

N. Frolova

E-mail:

npnuht@ukr.net

\begin{abstract}
This article summarizes the scientific, practical, commercial bases of modern methods of determining shelf life of nutrition products, including those of revitalizing action. The criteria for assessing food quality changes during storage were analyzed allowing to control the processes reaction rates that are responsible for product spoilage. It is demonstrated that for an adequate determining shelf life of nutrition products one should systematically approach selection of identification criterion of change of quality indicators during storage, establish and examine mechanisms of relevant processes under provisions and laws of food and physical chemistry, unveil reactions accompanied by loss of a complex of substances with biological effect. The promising way for forecasting expiry date and shelf life of separate groups of nutrition products is "accelerated ageing" and logical sequence of mathematical and statistical methods of processing results of the active experiment.

"Accelerated ageing" method - ASLT (Accelerated Shelf Life Testing) means accelerated change of quality indicators of a product under extreme conditions of storage (elevated temperature, high humidity etc.). Such a way allows significantly save time and control in express mode the key quality indicators. Realization of the ASLT method consists in choice of kinetic factors for acceleration of the process; realization of experimental studies concerning change in chosen quality indicators owing to kinetic factors of spoilage during a short time period; choice of an adequate kinetic model with extrapolation to real shelf life and using the obtained data for forecasting shelf life.

For determination of shelf life the theory of regression analysis with the construction and evaluation of the adequacy of the regression model on the basis of mathematical planning and processing of the results of the active experiment is applied. Determining real shelf life of nutrition products requires a comprehensive approach to studding physical, microbiological, oxidative processes during storage aimed at detection of signs of their spoilage: peroxides, free fatty acids, level of loss of functioning biologically active substances.
\end{abstract}

DOI: $10.24263 / 2225-2924-2018-24-5-21$ 


\title{
СУЧАСНІ СПОСОБИ ВИЗНАЧЕННЯ ТЕРМІНІВ ЗБЕРІГАННЯ ХАРЧОВИХ ПРОДУКТІВ I шляХИ їХ РОзвИткУ
}

\author{
Н.Е. Фролова \\ Національний університет харчових технологій
}

У статті узагальнено наукові, практичні, комериійні основи сучасних способів визначення термінів зберігання харчових продуктів, в тому числі оздоровчої дії. Проаналізовано критерії оцінювання змін якості харчових продуктів впродовж зберігання, ще дає змогу контролювати швидкість перебігу процесів псування продуктів. Показано, що для адекватного визначення термінів зберігання харчових продуктів необхідно системно підходити до обрання критеріїв ідентифікаиї змін показників, їх якості впродовж зберігання, встановлювати та досліджувати механізми відповідних процесів за положеннями $і$ законами харчової та фізичної хімії, розкривати реакиії, щьо супроводжуються втратами комплексу речовин біологічної дії.

Перспективним для прогнозування термінів придатності та зберігання окремих груп харчових продуктів є спосіб «прискореного старіння» ASLT (Accelerated Slielf Life Testing), що означає прискорену зміну показників якості продукту в екстремальних умовах зберігання (при підвищеній температурі, вологості тощо). Такий спосіб дає змогу значно заощадити час і контролювати в експрес-режимі ключові показники якості. Реалізачія способу ASLT полягає у виборі кінетичних факторів для прискорення процесу; реалізаиії експериментальних досліджень щодо змін обраних показників якості від кінетичних факторів псування за короткий період часу; виборі адекватної кінетичної моделі з екстраполяцією на реальний режим зберігання та використанні отриманих даних для прогнозування терміну зберігання.

Для встановлення термінів зберігання застосовується теорія регресивного аналізу з побудовою й оцінкою адекватності регресійній моделі на основі математичного планування й обробки результатів активного експерименту. Встановлення дійсних термінів зберігання харчових продуктів вимагає комплексного підходу до вивчення фізичних, мікробіологічних, окислювальних проиесів упродовж зберігання з метою виявлення ознак їх псування: перекисів, вільних жсирних кислот, ступеня втрати дійових біологічно активних речовин.

Ключові слова: термін зберігання, прочеси псування, критичні показники якості, програмування, тестування, кінетичні моделі.

Постановка проблеми. Використання в технологіях харчових продуктів сурогатів натуральних продуктів викликає у споживача бажання захистити себе від їх шкідливого впливу. Однією з соціальних форм такого захисту $\epsilon$ поширення продуктів оздоровчого харчування, адаптованих до організму людини [1].

Зростаюча потреба в оздоровчих харчових продуктах обумовлює підвищену увагу до визначення термінів їх придатності та зберігання. Водночас 
пошук раціонального рішення суперечливих вимог споживачів щодо мінімальної обробки продукту з можливістю тривалого зберігання вимагає від науковців і спеціалістів вдосконалювати методи визначення термінів зберігання на основі наукового встановлення та контролю факторів, що спричиняють початок і розвиток процесів псування.

Аналіз останніх досліджень і публікацій. Усі харчові продукти складаються з біоматеріалів, які з часом змінюють свої властивості, розкладаються та псуються. Процес псування - це об'єктивний процес. Його неможливо зупинити зовсім, можливо тільки цілеспрямовано управляти та сповільнювати.

Фахівці, до основних факторів впливу на процеси псування відносять правильний підбір рецептурних інгредієнтів харчового продукту, режими технологічного оброблення, способи упакування, транспортування, дотримання встановлених термінів зберігання за рекомендованих умов [2].

Для визначення раціональних термінів зберігання продуктів необхідно знати закономірності перебігу процесів псування, застосовувати сучасні методи моделювання. Враховуючи, що псування продуктів проходить переважно під час їх зберігання і $є$ функцією часу, моделі мають будуватися за законами кінетики [3]. Також терміни зберігання харчових продуктів, як правило, визначаються на підставі комерційної доцільності та вимог безпеки [4].

Значна кількість публікацій, присвячених визначенню термінів зберігання харчових продуктів, свідчить про широкий інтерес до цієї теми як серед фахівців харчових технологій [5], так і науковців усього світу [6].

Мета дослідження полягає в аналізі сучасних способів визначення термінів зберігання харчових продуктів та визначенні шляхів їх розвитку.

Викладення основних результатів дослідження. Обговорюючи сучасні способи визначення термінів зберігання, зазначимо, що нині випробування проводять за трьома напрямками:

- традиційні випробування відповідно до вимог документації з певною періодичністю;

- застосування методів математичного моделювання зміни якості харчових продуктів із прогнозуванням терміну зберігання;

- застосування прискорених способів старіння.

При традиційних випробуваннях можуть бути такі варіанти тестування [6]:

- оптимальних умов зберігання для підтримки найбільш тривалого реального терміну зберігання;

- типових (усереднених) умов зберігання продукту, які можна застосувати для терміну зберігання, прийнятного як для виробника, так і для споживача;

- несприятливих (екстремальних) умов зберігання, які забезпечують продукту безпеку «із запасом».

Для визначення терміну зберігання залежно від виду продукту і механізмів його псування, як правило, застосовують такі види тестів:

- мікробіологічні аналізи;

- хімічні аналізи;

- тестування фізичних показників (наприклад, вимірювання реологічних характеристик);

- органолептична оцінка. 
Для швидкого отримання необхідної інформації про терміни зберігання харчової продукції у світі, зазвичай, застосовується метод прискореного випробування терміну зберігання (ASLT - Accelerated Shelf-Life Test) або метод «штучного старіння» [7]. Поняття прискореного тестування терміну зберігання може бути застосоване до будь-якого продукту, для якого відома адекватна кінетична модель зниження якості. Цей метод дає змогу істотно скоротити тривалість експериментів за рахунок збільшення швидкості реакцій псування продукту [8; 9].

Властивості оздоровчих харчових продуктів вимагають більш чітких підходів до способів визначення терміну їх придатності та зберігання з системним контролем та управлінням біохімічними, фізико-хімічними процесами, не допускаючи руйнування та модифікацій комплексу біологічно активних речовин.

Терміном зберігання продукту буде час, після якого найбільш критичний (першочергово схильний до змін) показник якості (КПЯ) досягне рівня, неприйнятного для зберігання продукту і реалізації без втрат функціональних властивостей.

Контроль КПЯ надає можливість науково обгрунтувати терміни зберігання і придатності харчових продуктів, а на основі динаміки зміни КПК побудувати математичну модель, що враховує швидкість зміни кожного 3 критичних показників якості.

Для оздоровчих продуктів важливими є біотичні фактори, що розвиваються в середині продукту, зокрема стабільність джерела функціональних інгредієнтів, напрями технологічного оброблення; активність води (доступна вода); $\mathrm{pH}$ (загальна кислотність); наявність консервантів, включаючи сіль і прянощі; природна мікрофлора; доступний кисень; природні біохімічні фактори (ферменти, хімічні реагенти). До абіотичних факторів (зовнішні ризики) слід віднести тип теплового оброблення (концентрування, перегонка, сушіння тощо; склад газу у вільному просторі над продуктом в упаковці; відносна вологість, світло (УФ та ІЧ). Означені біотичні, абіотичні впливові фактори рідко діють незалежно, але вказаний розподіл факторів на групи створює зручну основу для обговорення. Зазначимо, що вони не завжди $є$ шкідливими, i в деяких випадках необхідні для розвитку запланованих властивостей продукту.

У таблиці зібрана інформація про процеси, які з різною інтенсивністю відбуваються в харчових продуктах при їх зберіганні, і впливові фактори, що можуть стати причиною псування $[4 ; 6 ; 10 ; 11]$.

\section{Таблиия. Процеси і впливові фактори}

\begin{tabular}{|c|c|c|}
\hline Харчовий продукт & $\begin{array}{c}\text { Процеси, за якими відбувається } \\
\text { псування }\end{array}$ & Впливові фактори \\
\hline 1 & 2 & 3 \\
\hline $\begin{array}{c}\text { Хрусткі борошняні } \\
\text { кондитерські вироби }\end{array}$ & $\begin{array}{c}\text { Міграція вологи (розм'якшення), } \\
\text { окислення, ламкість }\end{array}$ & $\begin{array}{c}\text { Волога, температура, кисень, } \\
\text { світло, механічні ушкодження }\end{array}$ \\
\hline Льодяники & Міграція вологи, кристалізація цукру & Температура, вологість \\
\hline Молочні продукти & $\begin{array}{c}\text { Окислення, згіркнення, кристалізація } \\
\text { лактози }\end{array}$ & Кисень, температура \\
\hline
\end{tabular}




\begin{tabular}{|c|c|c|}
\hline & & Продовження табл. \\
\hline 1 & 2 & 3 \\
\hline $\begin{array}{l}\text { Плодоягідна } \\
\text { сировина }\end{array}$ & $\begin{array}{c}\text { Ферментативне розм'якшення, } \\
\text { розмноження мікроорганізмів, } \\
\text { пошкодження, втрата вологи }\end{array}$ & $\begin{array}{c}\text { Температура, світло, волога, } \\
\text { механічні ушкодження }\end{array}$ \\
\hline Листові овочі & $\begin{array}{c}\text { Ферментативна активність, втрата } \\
\text { вологи, розмноження } \\
\text { мікроорганізмів }\end{array}$ & $\begin{array}{c}\text { Температура, світло, кисень, } \\
\text { активна вода }\end{array}$ \\
\hline Сухі зернові сніданки & $\begin{array}{c}\text { Міграція вологи (розм’якшення), } \\
\text { ретрограція крохмалю, окислення, } \\
\text { ламкість }\end{array}$ & $\begin{array}{l}\text { Волога, температура, } \\
\text { механічні ушкодження }\end{array}$ \\
\hline
\end{tabular}

Проведений аналіз теоретичних подань визначення термінів зберігання, опублікованих у сучасному інформаційному полі [2-10], дав змогу сформувати ряд ключових положень їх використання та розвитку, зокрема:

- при встановленні терміну зберігання першочергово слід оцінити ризики (впливові фактори), за якими ймовірна зміна якісних показників продукту 3 нарощуванням процесів псування;

- між процесами псування харчових продуктів існує певна кореляція, і в більшості випадків відбуваються всі процеси за різної інтенсивності. Як правило, вони пов'язані між собою за законами нелінійної залежності і проявляють стимулювання або пригнічують один одного;

- визначати характеристики готового продукту, що роблять його неприйнятним для споживача. Таким чином встановлюються критичні параметри якості, що обмежують термін зберігання. Для оздоровчих продуктів $є$ рівень діючих БАР, органолептичні властивості та показники безпеки;

- відхилення значень якісних показників готового продукту від початкових, що є сигналом початку процесів псування продукту. Інтенсивність перебігу процесів псування в продукті також залежить від стабільності показників якості вихідної сировини;

- використання методів математичного моделювання. Це дає змогу прогнозувати розвиток процесів псування як в регламентованих умовах, так і в екстремальних режимах. Отримана кінетична модель характеризує швидкість зміни критичних показників якості продукту (КПЯ) від ключових параметрів процесів, що мають місце при зберіганні.

Розвитком способів визначення термінів зберігання $\epsilon$ використання експрес-способу прискореного тестування - ASLT (Accelerated Slielf Life Testing) [7]. Термін «прискорене старіння» означає прискорену зміну показників якості продукту в екстремальних умовах зберігання (при підвищеній температурі, вологості тощо). Спосіб прискореного штучного старіння значно заощаджує час і забезпечує контроль ключових показників якості в експресрежимі.

Спосіб ASLT реалізується за такими етапами:

- вибір кінетичних факторів для прискорення процесу;

- експериментальні дослідження змін обраних показників якості від кінетичних факторів псування за короткий період часу. На цьому етапі вирішаль- 
не значення має валідність (обгрунтованість) вибору контрольованих показників якості;

- вибір адекватної кінетичної моделі з екстраполяцією на реальний режим зберігання;

- використання отриманих даних для прогнозування терміну зберігання .

У кінетичну модель обов'язково повинна включатися температура, значення якої істотно впливають на швидкість локальних хімічних реакцій. При цьому вводиться критерій $Q_{10}$, який показує, наскільки швидше відбувається реакція при підвищенні температури на кожні $10^{\circ} \mathrm{C}$. Відомо, що 3 підвищенням стандартної температури на $10^{\circ} \mathrm{C}$, швидкість хімічної реакції в рідких середовищах збільшується в два рази (формула 1):

$$
Q_{10}=\frac{\mathrm{K}_{t}+10}{K T},
$$

де К - швидкість хімічної реакції за досліджуваної температури $t$; $T$ - абсолютна температура.

Критерій $Q_{10}$ використовується для прогнозування очікуваного терміну зберігання харчових продуктів [6]. Якщо за температури $30^{\circ} \mathrm{C}$ показник $Q_{10}=2$ і продукт стабільний протягом десяти тижнів, то при стандартній температурі повітря в сховищі $\left(20^{\circ} \mathrm{C}\right)$ стабільність продукту становитиме: $2 \times 10$ тижнів $=$ $=20$ тижнів. Простота використання критерію $Q_{10}$ дає змогу швидко отримати необхідні результати при мінімальних практичних зусиллях.

Для багатокомпонентних оздоровчих продуктів визначення терміну зберігання на основі способу ASLT є актуальним за якісним контролем дійової БАР продукту. При цьому вводиться припущення про незалежність перебігу відповідних процесів. Тоді кожен процес псування буде контролюватися окремою дискретною величиною. Пропонується використовувати принцип контролю КПК, який кількісно характеризує динаміку зміни дійових БАР упродовж зберігання досліджуваного продукту.

Прикладом успішного використання прискореного методу тестування (ASLT $з$ використанням моделі Арреніуса і критерію Q10) є визначення терміну придатності функціонального напою на основі трав'яного червоного чаю (Hibiscus sabdariffa) і плодово-ягідних соків [8]. Функціональними інгредієнтами рецептури обрані сухі екстракти плодово-ягідної сировини. Новий функціональний напій призначений для профілактики серцево-судинних захворювань. Встановлено термін зберігання функціонального напою - 3,7 місяця за вмістом антоціанів, найменш стабільних БАР до зростання температури. Показано, що термін зберігання можна продовжити до $11-12$ місяців, якщо в рецептурі збільшити кількість сухих екстрактів з високим вмістом флавоноїдів

Для швидкопсувних продуктів, для яких критичним показником (КПЯ) $є$ зростання мікрофлори, успішно застосовуються моделі росту мікробів, побудовані за рівнянням Арреніуса або рівнянням Рутківського [12]. Для ряду жировмісних харчових продуктів досліджена залежність швидкості окислення жирів (КПЯ) від умов зберігання з використанням коефіцієнта Моно [13]. Зростання швидкості окислення ліпідів 3 ростом температури зберігання 
описується рівнянням Арреніуса, що з достатньою точністю дає змогу передбачити термін придатності продуктів дитячого харчування.

Згідно з літературними даними, у багатьох випадках залежність швидкості КПЯ від факторів псування при зберіганні задовільно описується рівнянням Арреніуса (формула 2):

$$
\mathrm{K}=\mathrm{K}_{0} \cdot \exp { }^{-\frac{E a}{R T}},
$$

де $\mathrm{K}_{0}-$ константа швидкості псування; $R$ - газова постійна; $T$ - абсолютна температура; $E a$ - енергія активації, додатковий енергетичний бар'єр, який необхідно подолати для запуску механізму псування.

В основі такого підходу лежить вивчення механізму і кінетики процесів, що визначають зниження $E a$ в процесі зберігання. Енергію активації процесу визначають за графіком залежності натурального логарифма константи швидкості процесу від зворотної температури процесу, вираженою в градусах Кельвіна.

Такий підхід успішно використовується для прогнозування термінів зберігання сухих харчових продуктів, соків, овочів, контролю зниження вмісту вітамінів оздоровчих продуктах, при прогнозуванні мікробної псування молокопродуктів і охолодженої риби [14].

Переваг для застосування даних з кінетики реакцій псування безліч. Це надає можливість використовувати стандартну методологію для аналізу даних, що давно успішно перевірені в дослідженнях з багатьох технологій [8; $10 ; 14 ; 15]$.

Ефективним способом встановлення термінів зберігання нових оздоровчих продуктів $є$ застосовування теорії регресивного аналізу для побудови й оцінки адекватності регресійній моделі на основі математичного планування й обробки результатів активного експерименту [5]. Функцією відгуку в цьому випадку є період (доба), що відповідає терміну зберігання продукту. Як контроль використовуються зразки до моменту початку погіршення органолептичних показників. Враховувати мікробіологічні, фізико-хімічні показники зміни якості при псуванні дають змогу моделі багатофакторного дисперсійнорегресійного аналізу. У таких моделях відгук (модельований параметр) відіграє роль залежної змінної, а фактори, що впливають на модельований параметр, - роль незалежних змінних з обмеженим числом можливих значень (рівнів). Це істотно скорочує кількість спостережень, дає змогу провести коректний статистичний аналіз, що виключає випадкові взаємодії факторів.

Окислення ліпідів $є$ одним 3 основних процесів, що обмежують терміни зберігання харчових продуктів. Швидкість окислення ліпідів з ростом температури зберігання зростає експоненціально і тому досить добре описується рівнянням Арреніуса [13].

Окислення ліпідів призводить до утворення безлічі різних з'єднань, які можуть формувати небажаний смак і запах. Наукові дослідження підтверджують зв'язок органолептичних показників з результатами вимірювань тіобарбітурового числа (показника окислення ліпідів) і накопиченням летких сполук, які виділяються з вільного простору над пробами продукту [14] . 
У переважній більшості здатність харчових ліпідів до псування залежить від ступеня ненасиченості складових їх жирних кислот, їх доступності та наявності активаторів або інгібіторів [6].

Рушійним фактором псування ліпідів $\epsilon$ активність ліпаз як ендогенного, так і мікробіологічного походження. Це запускає зміни функціональних властивостей молочних продуктів, а також появу речовин, носіїв мильного або згірклого присмаків. Оскільки смакоароматичний поріг цих речовин, зазвичай, низький (наприклад, для гексанової кислоти - 14 ppm), то навіть дуже слабка активність ліпази може істотно впливати на якість продукту.

Проблеми відповідності заявленого терміну придатності функціональних кондитерських виробів фактичному терміну зберігання обумовлюють розробку способів встановлення реальних строків 3 прогнозуванням розвитку процесів втрати дійових БАР. Такі висновки грунтуються на заміни рецептурних функціональних компонентів на інші з метою зниження собівартості продукції. Це призводить до інформаційної фальсифікації та до змін показників якості виробів і заявлених термінів зберігання.

Особливо це стосується жировмісних борошняних кондитерських виробів, збагачених функціональними інгредієнтами. Практично всі зміни якості таких кондитерських виробів при зберіганні пов'язані зі змінами стану жирової або водної фази. Так, зміна окислювальної стабільності використовуваних жирів на вході в технологічну систему призводить до коливань ії стабільності на виході та зміни терміну зберігання оздоровчого продукту [16].

Встановлення дійсних термінів зберігання функціональних кондитерських виробів вимагає комплексного підходу до вивчення фізичних, мікробіологічних, окислювальних процесів впродовж зберігання і насамперед до обгрунтування вимог до показників окислювального псування використовуваних жирів і зменшення вмісту насичених жирних кислот і транс-ізомерів ненасичених жирних кислот [10]. У цьому аспекті ефективно також досліджувати зміни органолептичних, фізико-хімічних показників якості кондитерських виробів з прогнозуванням кінцевого терміну зберігання. Це забезпечить виробництво функціональних кондитерських виробів високої якості з подовженими термінами зберігання.

За показниками окисного псування жирів розроблені методи прогнозування терміну зберігання згущених молочних консервів, борошняних кондитерських виробів 3 масовою часткою вологи менше $10 \%$ за зміною жирокислотного складу, часу індукції ліпідів, хімічного складу токоферолів [12].

Г.Г. Жариковою із співавторами [17] запропонований спосіб визначення терміну придатності шоколадних цукерок, заснований на термічному старінні досліджуваних зразків цукерок при витримці за підвищених температур протягом одного місяця. За вмістом у досліджених зразках загальної кількості мікроорганізмів визначається термін придатності досліджуваних зразків цукерок.

У дослідженні I.A. Рогова [18] показано зв'язок терміну зберігання біоферментірованних молочних продуктів 3 осмотичними умовами і ступенем активності води. Вода, як відомо, є основним компонентів всіх біологічних систем, в тому числі харчових продуктів. 


\section{Висновки}

1. Обгрунтування реального терміну зберігання базується на поняттях безпеки, якості та на комерційних рішеннях.

2. Термін придатності харчового продукту означає період часу, протягом якого цей продукт реалізується без істотних функціональних властивостей. Термін зберігання — це крайній термін зберігання продукту, після закінчення якого продукт непридатний для вживання.

3. Перевіреним способом прогнозування терміну зберігання харчових продуктів є спосіб прискореного тестування - ASLT (Accelerated Slielf Life Testing). Це спосіб прискореного штучного старіння, заснований на застосуванні одиничного чинника прискорення. Найчастіше таким фактором, як зазначалося вище, виступає температура. Розвитком цього способу є використання декількох факторів прискорення, що забезпечує отримання адекватного коефіцієнта $Q_{10}$ при мінімальній помилці прогнозу.

\section{Література}

1. Українець А.І., Сімахіна Г.О. Технологія оздоровчих харчових продуктів: курс лекцій для студентів «Харчові технології і інженерія» денної і заочної форм навчання. Київ: НУХТ. 2009. 310 с.

2. Колтунов В.А., Белінська Е.В. Технологія зберігання продовольчих товарів: підруч. Київ: Центр навч. літератури, 2014. - 138 с.

3. Силка І.М., Гуць В.С., Фролова Н.Е. Кінетична модель зміни якості новітніх харчових продуктів. Харчова наука і технологія. 2016. Vol. 10, № 1. С. 11-15.

4. Килкас Д., Субраманиам П.Стабильность и срок годности. Безалкогольные напитки, соки, пиво и вино: учеб. Санкт-Петербург: Профессия, 2012. 440 с.

5. Фролова Н.Е. Теоретичне обгрунтування і розроблення технологій натуральних концентрованих ароматизаторів із ефіроолійної сировини: автореф. дис. д-ра техн. наук: спец. 05.18.06 «Технологія жирів, ефірних масел і парфумерно-косметичних продуктів» / НУХТ. Київ, 2017. 48 с.

6. Стеле Р. Срок годности пищевых продуктов: расчет и испытание: учеб. 2006. 480 с.

7. A general protocol for evaluating new or existing products under accelerated shelf-life testing (ASLT). Загальний протокол для оцінки нових або існуючих продуктів під прискорених випробувань терміну придатності (ASLT).

8. Матвеева Н.А., Хасанов А.Р. Прогнозирование срока годности методом ускоренного тестирования в технологии напитков функционального назначения. Научный журнал НИУ ИТМО. Серия «Процессы и аппараты пищевых производств». 2016. № 4. C. $75-82$.

9. Reid D. et al. A new method for accelerated shelf life prediction for frozen foods. Journal of the Science of Food and Agriculture. 2003. Vol. 83. No. 10. P. 1018-1021.

10. Скокан Л.Е., Аксенова Л.М., Кондратьев Н Б. Основные аспекты прогнозирования и обеспечения увеличенных сроков годности кондитерских изделий. Актуальные проблемы в области создания инновационных технологий хранения сельскохозяйственного сырья и пищевых продуктов: матер. Всерос. конф., г. Углич, 20-22 июня, 2010 г. Углич, 2010. C. 229.

11. Штерман С.В. и др. Обобщенная методика прогнозирования сроков длительного хранения пищевых продуктов. Пищевая промышленность. 2014. № 5. С. 24-28.

12. Александровский С.А. Применение уравнения Аррениуса для оценки потери питательных компонентов при пастеризации молока. Вестник Казанского технологического университета. 2014. № 24, Т. 17. С. 178-181. 
13. Родникова А.А. и др. Применение метода ускоренного старения для определения срока годности масла подсолнечного рафинированного дезодорированного. Кондитерское производство. 2014. № 2. С. 30-32.

14. Сидоренко О.В. Наукове обгрунтування і формування споживних властивостей продуктів 3 прісноводної риби та рослинної сировини: дис. докт. техн. наук: 05.18.05 «Товарознавство». КНТЕУ. Київ, 2009. 327 с.

15. Фролова Н.Е., Коваль О.А., Силка І.М. Прогнозування строку придатності натуральних ароматизаторів із ефіроолійної сировини. Товари і ринки. 2011. № 2. С. 149-155.

16. Дорохович А., Гавва Е., Дорохович В.Продлить хранение кондитерских изделий вполне возможно. Хлібопекарська і кондитерська промисловість Украӥни. 2012. № 1. C. $14-17$.

17. Патент 2380701 РФ, МПК 7G01C1, G01N 33/02. Способ определения срока годности шоколадных конфет по микробиологическим показателям / Жарикова Г.Г., Леонова И.Б.; заявитель и патентообладатель Жарикова Г.Г. № 2008126418/13; заявл. 10.07.08; опубл. 27.01.10, Бюл. № 3, 2010 г.

18. Рогов И.А. и др. Исследование зависимости срока годности биоферментированных кисломолочных продуктов от осмотических условий и активности воды. Биотехнология. Вода и пищевые продукты: Сб. матер. Междунар. науч.-практ. конф.. (Москва, 11-13 марта 2013 г.). Москва, 2013. С. 323. 